\title{
FLT3 Internal Tandem Duplication Mutation, c MPL and CD34 Expressions Predict Low Survival in Acute Myeloid Leukemia Patients
}

\author{
Eman K. Ebrahim ${ }^{1}$, Magda M. Assem ${ }^{1}$, Ahmed I. Amin ${ }^{2}$, Mahmoud M. Kamel ${ }^{1}$, Yomna M. \\ ElMeligui $^{1}$ and Ayman M. Metwally ${ }^{3 *}$ \\ ${ }^{1}$ Clinical Pathology Department, National Cancer Institute, Cairo University, Cairo, Egypt, \\ ${ }^{2}$ Chemistry Department, Faculty of Science, Cairo University, Cairo, Egypt, \\ ${ }^{3}$ Technology of Medical Laboratory Department, College of Applied Medical Sciences, Misr University for Science and \\ Technology, 6 October, Egypt.
}

ARTICLE INFO

Article history:

Received 21 February 2016

Accepted 06 April 2016

Keywords:

Acute myeloid leukemia;

FLT3 ITD;

CD34;

cMPL;

EphA4;

Survival.

\begin{abstract}
A B S T R A C T
The study aims to detect FMS-like tyrosine kinase-3 internal tandem duplicate (FLT3 ITD) mutation, Myeloproliferative leukemia virus oncogene (cMPL) and Ephrin A 4 receptor (EphA4) expressions in Acute myeloid leukemia (AML) and their correlation to patient's clinicopathological characteristics and survival. RNA was extracted from blood samples of 58 AML patients (39 adults and 19 children) and 20 age and sex matched controls. FLT3 ITD mutation, cMPL and EphA4 expression was studied using RT-PCR and correlated to the clinical and survival data of the patients. FLT3 ITD mutation, cMPL and EphA4 expression was positive in $35.9 \%, 76.9 \%$ and $56.4 \%$ of adult AML patients respectively and in $15.8 \%, 47.4 \%$ and $36.8 \%$ of pediatric AML patients respectively. $76.9 \%$ of adult and $89.5 \%$ of pediatric patients expressed CD33. $64.1 \%$ of adults and $42.1 \%$ of children expressed CD34. CD34 expression was significantly associated with both FLT3 ITD mutation and cMPL expression. CD34, FLT3 and cMPL negative cases have significantly higher overall survival than positive cases. In conclusion, CD34 expression is significantly associated with both FLT3 ITD mutation and cMPL expression which could be used as a marker for low survival. Normal FLT3 and negative expression of CD34 and cMPL may predict a longer overall survival. Further studies are needed to investigate the mechanism that may correlate CD34 to both markers.
\end{abstract}

\section{Introduction}

Acute myeloid leukemia (AML) represents a group of clonal hematopoietic stem cell disorders in which both failure to differentiate and over-proliferation of the stem cell compartment result in accumulation of nonfunctional myeloblasts, impaired hematopoiesis and cytopenias. However, the specific cause in any individual patient is usually unknown ${ }^{[1]}$.

Discovering the molecular abnormalities that are involved in carcinogenesis and progression of acute leukemia is an important strategy for detection and treatment of the disease. Molecular alterations in AML are divided into 2 groups. The first group includes mutations that activate the signal transduction pathway, while the second group comprises mutations that affect the cell cycle components ${ }^{[2]}$.

The FMS-like tyrosine kinase-3 (FLT-3) a class III

\footnotetext{
* Corresponding author.
}

E-mail address: receptor tyrosine kinase family, is primarily expressed by hematopoietic cells and plays an important role in hematopoiesis. FLT-3 is expressed in the majority of acute leukemia and mutation is associated with poor prognosis ${ }^{[3]}$.

Myeloproliferative leukemia virus oncogene, MPL a homodimeric receptor activated by thrombopoietin (THPO) and is mutated in myeloproliferative disorders. This receptor appears to play an important role in the pathogenesis of acute leukemia, particularly AML ${ }^{[4]}$. Also the expression of, c-MPL, has been suggested to represent an adverse prognostic factor in myelodysplasia and acute myeloid leukemia (AML) ${ }^{[5]}$.

Ephrin receptors (Eph proteins) are the largest family of RTKs and bind to Eph receptor-interacting (ephrin) ligands, which are glycosylphosphatidylinositol-linked or transmembrane ligands at sites of cell-cell contact. Fourteen members of the Eph family of RTK have been identified in mammals, which are divided into two groups, 
the EphA and EphB family ${ }^{[6]}$. EPHA4, a member of the EPHA receptors, has been demonstrated to be elevated in various human cancers and involved in the tumor progression ${ }^{[7]}$. EphA4 overexpression has been reported in many cancers including non-small cell lung cancer ${ }^{[8]}$, pancreatic cancer ${ }^{[9]}$, gastric cancer ${ }^{[10]}$, breast cancer ${ }^{[11]}$ and cervical cancer ${ }^{[12]}$.

The aim of the present work is to study the FLT-3 ITD mutation and the expression of cMPL and EPhA4 in adult and pediatric AML patients and to correlate the gene expression profile to the different clinical and survival data of the patients.

\section{Subjects and Methods \\ Subjects}

The present work has been carried out according to the Declaration of Helsinki for experiments involving humans.

The present study included a total of 58 patients (39 adults and 19 pediatric) with de novo acute myeloid leukemia selected from pediatric and medical oncology departments at the National Cancer Institute, Cairo University, Egypt. A control group with 20 (10 males and 10 females) age and sex matched subjects were involved in the study.

\section{Inclusion criteria:}

Patients involved in the present study are newly diagnosed Acute Myeloid Leukemia (AML) cases that did not receive any type of therapy.

Before enrolling in the study, patients were subjected to complete medical history, physical examination, complete blood count, bone marrow examination and immunophenotyping by flowcytometer for CD34 and myeloid associated antigens ( CD13, CD33, CD14 and CD15), biochemical profile measurements including liver and kidney function tests, fasting blood sugar, LDH and CSF examination. In addition, radiological examination including chest $\mathrm{X}$ ray, bone scan, CT scan and abdominopelvic ultrasound was performed. After diagnosis, patients were treated according to the institute ongoing patients with de novo AML.

Patients below 16 years were subjected to the ADE protocol for induction of remission and to MIDAC protocol for consolidation as follows:

a) Induction of remission (4 courses): ARA/C: $100 \mathrm{mg}$ / $\mathrm{m} 2$ intravenous at days 1 and 2 . Then, $100 \mathrm{mg} / \mathrm{m} 2$, every 12 hours, intravenous push days3-8. Adriamycin: $25 \mathrm{mg} / \mathrm{m} 2$, intravenous infusion days 3, 4, 5. Vepeside: $100 \mathrm{mg} / \mathrm{m} 2$, over 60 minutes infusion days $6,7,8$.

b) Consolidation ( 2 courses): Mitoxantrone: $10 \mathrm{mg} / \mathrm{m} 2$, over 6 hours intravenous infusion days 1- 5. Cytarabine: $1 \mathrm{mg} / \mathrm{m} 2 / 12 \mathrm{hrs}$, over $2 \mathrm{hrs}$ intravenous infusion, days $1-3$.

Patients with de novo AML above the age of 16 were subjected to protocol for induction of remission as follows:

a) Induction of remission: Adriamycin: $45 \mathrm{mg} / \mathrm{m} 2$ intravenous from day1-3. ARA-C: $100 \mathrm{mg} / \mathrm{m} 2$ intravenous from days 1-7. b) Consolidation: High dose ARA-C, Mitoxantrone) for 2 cycles as follows: ARA-C: $1 \mathrm{gm} / \mathrm{m} 2$, over 3 hours infusion, every $12 \mathrm{hrs}$, from day1- 3. Mitoxantrone: 12 $\mathrm{mg} / \mathrm{m} 2$, intravenous over $2 \mathrm{hrs}$, from day3- 5 .

Patients with de novo AML (M3) were subjected to the following Protocol:

a) Induction of remission: ATRA (all trans retinoic acid): $45 \mathrm{mg} / \mathrm{m} 2$ every 12 hours till complete remission or maximum 90 days. Adriamycin: $60 \mathrm{mg} / \mathrm{m} 2$, from days 13 , for 3 cycles.

b) Maintenance therapy: ATRA: $45 \mathrm{mg} / \mathrm{m} 2$, for 2 weeks, every 3 months, for 2 years. 6-Mercaptopurine: $60 \mathrm{mg} / \mathrm{m} 2$ in the morning before breakfast. Methotrexare: $20 \mathrm{mg} / \mathrm{m} 2$ intravenous once weekly.

Response to therapy was evaluated according to the World Health Organization (WHO) criteria, where complete remission (CR) was achieved when the patient expressed a hemoglobin percentage equal or more than $10 \mathrm{gm} / \mathrm{dl}$, platelet count equal to or more than $150.000(109 / \mathrm{L})$, white cell count equal to or more than $3000(109 / \mathrm{L})$, (with normal differential count) and the bone marrow is normocellular (with normal differential count or presence of less than 5\% blast cells). Finally, all clinical laboratory and radiological manifestations of acute leukemia should be absent.

\section{Methods:}

Following approval from the ethical committee of the National Cancer Institute, Cairo University, $3 \mathrm{ml}$ venous blood was obtained from each patient by a sterile venipuncture, the samples were put in sterile vacutainers containing EDTA as anticoagulant. Total RNA was extracted from the blood samples using QIA amp RNA blood kit (Catalog No. 52304). RNA samples were quantified and one cycle of reverse transcription at $55^{\circ} \mathrm{C}$ for 30min. was done using RT-PCR kit from Qiagen (Catalog number: 12110007).

PCR amplification for FLT-3 ITD mutation detection and MPL, EPHA-4 and $\beta$ actin expression.

The primer sequences (Operon primers) used for PCR amplification of FLT-3 ITD, MPL, EPHA-4 and $\beta$ actin are shown in Table 1.

After reverse transcription, cDNA samples were subjected to PCR amplification according to the following protocol: initial denaturation at $94^{\circ} \mathrm{C}$ for $5 \mathrm{~min}$ followed by 32 cycles of denaturation at $94^{\circ} \mathrm{C}$ for $60 \mathrm{sec}$, annealing for $60 \mathrm{sec}$ at: $60^{\circ} \mathrm{C}$ for $\mathrm{FLT} 3,59^{\circ} \mathrm{C}$ for cMPL and EPHA-4 and $57^{\circ} \mathrm{C}$ for $\beta$ actin and extension at $72^{\circ} \mathrm{C}$ for $60 \mathrm{sec}$. Final extension was carried out at $72^{\circ} \mathrm{C}$ for 10 $\min$.

The amplified PCR products were electrophoresed on $2 \%$ agarose gel (Sigma) stained with ethidium bromide $(5 \mu \mathrm{g} / \mathrm{ml})$ and visualized under ultraviolet illumination. DNA bands for FLT-3, MPL, EPHA-4 and $\beta$-actin were identified using molecular weight marker of $100 \mathrm{bp}$ DNA ladder (Promega Corp, Cat.\# G2101).

\section{Statistical analysis}

SPSS for Windows (version 12.0, SPSS, Chicago, IL, USA) was used for data management. Chi-square and Fisher's exact test were used for testing proportion 
Table 1: Primer sequences (Operon primers) for FLT-3, MPL, EPHA-4 and $\beta$ actin.

\begin{tabular}{|c|c|c|c|c|}
\hline Marker & Sense primer & Antisense primer & $\begin{array}{l}\text { Annealing } \\
\text { temp. }\end{array}$ & $\begin{array}{l}\text { Product } \\
\text { size }\end{array}$ \\
\hline FLT-3 & 5'-AGCAATTTAGGTATGAAAGCCAG-3' & 5'-ССТТСССАААСТСТАААТТТТСТСТ-3' & $60 \mathrm{C}^{\circ}$ & $140 \mathrm{bp}$ \\
\hline MPL & 5'-CAC ACT ACA GGA GAC TGA GGC-3' & 5'-GGCTGC TGC CAA TAG CTT CC-3' & $59 \mathrm{C}^{\mathrm{o}}$ & $348 \mathrm{bp}$ \\
\hline ЕРНА-4 & 5'-AGTCCTTCTGGTCTCTGTCTC-3' & 5'-CTTCATCCGCTTCTTGTTTGG-3' & $59 \mathrm{C}^{\mathrm{o}}$ & $115 \mathrm{bp}$ \\
\hline$\beta$ actin & $\begin{array}{l}\text { 5'-TGACGGGGTCACCCACACTGTGCCC } \\
\text { ATCTA3' }\end{array}$ & $\begin{array}{l}\text { 5'-CTAGAAGCATTTGCGGTGGACGATG } \\
\text { GAGGG-3' }\end{array}$ & $57 \mathrm{C}^{\mathrm{o}}$ & $661 \mathrm{bp}$ \\
\hline
\end{tabular}

independence. Non parametric t- test compared means of the two groups. Kaplan- Meier was used for estimating survival and Log- rank test compared the curves. ROC (Receiver- Operator Characteristic) curves were used to define cut-off levels for quantitative variables according to results of the studied markers. Data were presented as mean \pm SD (or median) and frequencies (\%). P value is significant at $<0.05$ levels.

\section{Results}

Fifty Eight patients were involved in the study, 39 adult and 19 pediatric patients. The clinicopathological characteristics of the adult and pediatric patients are shown in Table 2.

Table 2: Clinicopathological characteristics of 58 AML patients (39 adults and 19 pediatrics) involved in the study..

\begin{tabular}{|c|c|c|}
\hline $\begin{array}{l}\text { Clinicopathological } \\
\text { characteristics }\end{array}$ & $\begin{array}{c}\text { Adults } \\
(39)\end{array}$ & $\begin{array}{l}\text { Pediatrics } \\
\text { (19) }\end{array}$ \\
\hline $\begin{array}{l}\text { Age } \\
\text { Range } \\
\text { Median }\end{array}$ & $\begin{array}{c}22-66 \\
45\end{array}$ & $\begin{array}{c}2-16 \\
11\end{array}$ \\
\hline $\begin{array}{l}\text { Sex } \\
\text { Male } \\
\text { Female }\end{array}$ & $\begin{array}{l}18(46.2 \%) \\
21(53.8 \%)\end{array}$ & $\begin{array}{l}12(63.2 \%) \\
7(36.8 \%)\end{array}$ \\
\hline $\begin{array}{l}\text { Hb }(\mathbf{g} / \mathbf{d l}) \\
\text { Range } \\
\text { Mean } \pm \text { SD }\end{array}$ & $\begin{array}{c}4.4-12.10 \\
7.7 \pm 1.9\end{array}$ & $\begin{array}{c}4.8-13.90 \\
7.1 \pm 1.8\end{array}$ \\
\hline $\begin{array}{l}\text { TLC }\left(\mathbf{x} 10^{6} / \mathbf{m m}^{3}\right) \\
\text { Range } \\
\text { Median }\end{array}$ & $\begin{array}{c}14-325 \\
45\end{array}$ & $\begin{array}{c}26-259 \\
74\end{array}$ \\
\hline $\begin{array}{l}\text { Platelets }\left(\mathbf{x} 10^{\mathbf{6}} / \mathbf{m m}^{\mathbf{3}}\right) \\
\text { Range } \\
\text { Mean } \pm \text { SD }\end{array}$ & $\begin{array}{c}4.0-301.0 \\
74.9 \pm 28.9\end{array}$ & $\begin{array}{l}8.0-256.0 \\
91.6 \pm 35.6\end{array}$ \\
\hline $\begin{array}{l}\text { PB blasts }(\%) \\
\text { Range } \\
\text { Median }\end{array}$ & $\begin{array}{c}12-93.0 \\
61\end{array}$ & $\begin{array}{c}29.0-91.0 \\
63\end{array}$ \\
\hline $\begin{array}{l}\text { BM blasts }(\%) \\
\text { Range } \\
\text { Median }\end{array}$ & $\begin{array}{c}12.0-93.0 \\
61\end{array}$ & $\begin{array}{c}29.0-91.0 \\
63\end{array}$ \\
\hline $\begin{array}{l}\text { CD33 } \\
+\mathrm{ve} \\
-\mathrm{ve}\end{array}$ & $\begin{array}{l}30(76.9 \%) \\
9(23.1 \%)\end{array}$ & $\begin{array}{c}17(89.5 \%) \\
2(10.5 \%)\end{array}$ \\
\hline $\begin{array}{l}\text { CD34 } \\
+\mathrm{ve} \\
-\mathrm{ve}\end{array}$ & $\begin{array}{l}25(64.1 \%) \\
14(35.9 \%)\end{array}$ & $\begin{array}{l}8(42.1 \%) \\
11(57.9 \%)\end{array}$ \\
\hline
\end{tabular}

$\mathrm{Hb}=$ Hemoglobin, TLC $=$ Total Leucocytic Count, PB blasts $=$ Peripheral Blood blasts, BM blasts = Bone Marrow blasts. 
Patients were classified according to the French American and British classification (FAB) into to following: Nineteen patients (32.75\%) M1, 24 patients (41.37\%) M2, 9 patients (15.5\%) M4 and 6 patients (10.3\%) M5.

The results of this study showed that in adult group, 14 cases were positive for FLT-3 ITD mutation $(35.9 \%)$ and 25 were negative $(64.1 \%)$. Thirty cases $(76.9 \%)$ were positive for cMPL expression and 9 patients $(23.1$ $\%)$ were negative. However, 22 AML patients (56.4\%) were positive for EphA4 expression and 17 patients $(43.6 \%)$ were negative (Table 3 ).

For the pediatric patients, 3 AML patients $(15.8 \%)$ were positive for FLTT-3 ITD mutation and 16 patients (84.2\%) were negative, while 9 AML patients $(47.4 \%)$ were positive for cMPL expression and 10 patients (52.6\%) were negative. Regarding EphA4 expression, 7 patients $(36.8 \%)$ were positive and $12(63.2 \%)$ were negative (Table 3).

The correlation between the expression of the studied markers and the clinicopathological criteria of the adult patients are shown in Table 4. EphA4 expression is significantly associated with both age and sex of the patients. However FLTT-3 ITD mutation and cMPL expression did not shows any significant correlation with the clinical characteristics of the patients.

Table 3: Expression profile of FLT-3, cMPL and EphA4 in adult and pediatric AML patients.

\begin{tabular}{|l|c|c|}
\hline \multicolumn{1}{|c|}{ Marker } & Adults & Pediatrics \\
\hline FLT-3 ITD & & \\
+ve & $14(35.9 \%)$ & $3(15.8 \%)$ \\
-ve & $25(64.1 \%)$ & $16(84.2 \%)$ \\
\hline cMPL & $30(76.9 \%)$ & $9(47.4 \%)$ \\
+ve & $9(23.1 \%)$ & $10(52.6 \%)$ \\
-ve & $22(56.4 \%)$ & $7(36.8 \%)$ \\
EphA4 & $17(43.6 \%)$ & $12(63.2 \%)$ \\
+ve & & \\
-ve & & \\
\hline
\end{tabular}

FLT-3 ITD = FMS-like tyrosine kinase-3 Internal Tandem Duplication, cMPL = Myeloproliferative leukemia virus oncogene, EphA4 = Ephrin A 4 receptor.

Table 4: The correlation between the 3 markers and patients' criteria in adult AML group.

\begin{tabular}{|c|c|c|c|c|c|c|}
\hline \multirow{2}{*}{$\begin{array}{l}\text { Patient } \\
\text { characteristics }\end{array}$} & \multicolumn{2}{|c|}{ FLT-3 ITD } & \multicolumn{2}{|c|}{ cMPL } & \multicolumn{2}{|c|}{ EPhA4 } \\
\hline & $\begin{array}{l}+ \text { +ve } \\
(14) \\
\end{array}$ & $\begin{array}{l}-\mathbf{v e} \\
(25) \\
\end{array}$ & $\begin{array}{l}\text { +ve } \\
(30) \\
\end{array}$ & $\begin{array}{c}- \text { ve } \\
(9)\end{array}$ & $\begin{array}{l}+\mathbf{v e} \\
(22) \\
\end{array}$ & $\begin{array}{l}\text { - ve } \\
(17)\end{array}$ \\
\hline \multirow{2}{*}{$\begin{array}{l}\text { Mean Age } \\
\text { P value }\end{array}$} & 46.8 & 40.6 & 45.5 & 38.8 & 47.13 & 39.47 \\
\hline & \multicolumn{2}{|c|}{0.117} & \multicolumn{2}{|c|}{0.080} & \multicolumn{2}{|c|}{$0.0223 *$} \\
\hline \multirow{2}{*}{$\begin{array}{l}\text { Sex } \\
\text { Males } \\
\text { Females } \\
\text { P value } \\
\end{array}$} & $\begin{array}{l}7 \\
7 \\
\end{array}$ & $\begin{array}{l}11 \\
14 \\
\end{array}$ & $\begin{array}{c}11 \\
6 \\
\end{array}$ & $\begin{array}{c}19 \\
3 \\
\end{array}$ & $\begin{array}{c}13 \\
4 \\
\end{array}$ & $\begin{array}{c}9 \\
13 \\
\end{array}$ \\
\hline & \multicolumn{2}{|c|}{0.718} & \multicolumn{2}{|c|}{0.114} & \multicolumn{2}{|c|}{$0.026 \square$} \\
\hline \multirow{2}{*}{$\begin{array}{l}\text { Mean Hb } \\
P \text { value }\end{array}$} & 8.2 & 7.4 & 7.78 & 7.44 & 7.66 & 7.76 \\
\hline & \multicolumn{2}{|c|}{0.110} & \multicolumn{2}{|c|}{0.322} & \multicolumn{2}{|c|}{0.436} \\
\hline \multirow{2}{*}{$\begin{array}{l}\text { Mean Blasts } \\
\text { P value }\end{array}$} & 58.1 & 55.9 & 54.8 & 63 & 54.90 & 57.35 \\
\hline & \multicolumn{2}{|c|}{0.39} & \multicolumn{2}{|c|}{0.200} & \multicolumn{2}{|c|}{0.384} \\
\hline \multirow{2}{*}{$\begin{array}{l}\text { Mean TLC } \\
\text { P value }\end{array}$} & 70.7 & 87.16 & 91.76 & 46.22 & 78 & 85.41 \\
\hline & \multicolumn{2}{|c|}{0.26} & \multicolumn{2}{|c|}{0.060} & \multicolumn{2}{|c|}{0.385} \\
\hline \multirow{2}{*}{$\begin{array}{l}\text { Mean Platelets } \\
\text { P value }\end{array}$} & 65.69 & 79.11 & 72.6 & 81.44 & 68.81 & 82.17 \\
\hline & \multicolumn{2}{|c|}{0.087} & \multicolumn{2}{|c|}{0.214} & \multicolumn{2}{|c|}{0.0778} \\
\hline
\end{tabular}

$\mathrm{Hb}=$ Hemoglobin, TLC = Total Leucocytic Count, FLT-3 ITD = FMS-like tyrosine kinase-3 Internal Tandem Duplication, $\mathrm{cMPL}=$ Myeloproliferative leukemia virus oncogene, EphA4 $=$ Ephrin A 4 receptor. $*=$ statistical significance at $\mathrm{P}<0.05$. 
The correlation between the studied markers and the clinicopathological criteria of the pediatric group are shown in Table 5. Only EpHA4 expression is significantly associated with the age of the patients $(\mathrm{P}=$ 0.024).

By studying the correlation between the investigated markers and CD33 and CD34 expression in adult group, we found a highly significant correlation between CD34 expression and both FLT-3 ITD mutation $(\mathrm{P}=0.00047)$ and cMPL expression ( $\mathrm{P}<0.05)$ (Table 6).

Table 7 shows the correlation between the studied markers (FLT-3 ITD mutation, cMPL and EphA4 expressions) and CD33 and CD34 expression in the pediatric group. The results showed that FLT-3 ITD mutation is significantly associated with CD34 expression ( $\mathrm{P}=0.026$ ). Also cMPL expression is highly associated with CD34 expression $(\mathrm{P}=0.0028)$.

The overall survival results showed that the median survival was 2 months (1.1-2.9) among adults and 15 months (11.5-18.4) among pediatrics. The overall survival was significantly higher in patients with CD34 negative than those with CD34 positive $(\mathrm{P}<0.001)$ (Fig. 1).

Moreover, the overall survival was significantly higher in patients negative for both FLT-3 ITD mutation ( $\mathrm{P}<$ 0.001) (Fig. 2) and cMPL expression (Fig. 3) $(\mathrm{P}<0.001)$ than FLT-3 ITD mutant and cMPL +ve patients. However, there was no significant correlation for the overall survival between patients positive and those negative for EphA4 expression $(\mathrm{P}=0.312)$ (Fig. 4).

\section{Discussion}

Acute myeloid leukemia is an aggressive myeloid neoplasm characterized by $\geq 20 \%$ myeloblasts in the blood or bone marrow ${ }^{[13]}$.

Recently, a lot of information has become available regarding genetic abnormalities that occur in acute myeloid leukemia and their influence on disease progression and recurrence. These abnormalities will be helpful for future targeted therapy and designing therapies targeted against particular genetic pathways [13]

Table 5: The correlation between the studied markers and the clinicopathological criteria of pediatric AML patients.

\begin{tabular}{|c|c|c|c|c|c|c|}
\hline \multirow{2}{*}{ Patient characteristics } & \multicolumn{2}{|c|}{ FLT-3 ITD } & \multicolumn{2}{|c|}{ cMPL } & \multicolumn{2}{|c|}{ EPhA4 } \\
\hline & $\begin{array}{c}+ \\
(3)\end{array}$ & $\begin{array}{c}- \\
(16)\end{array}$ & $\begin{array}{c}+ \\
(9) \\
\end{array}$ & $\begin{array}{c}- \\
(10)\end{array}$ & $\begin{array}{l}+ \\
(7) \\
\end{array}$ & $\begin{array}{c}- \\
(12)\end{array}$ \\
\hline \multirow{2}{*}{$\begin{array}{l}\text { Age } \\
\text { median } \\
\mathrm{P} \text { value }\end{array}$} & 13 & 11 & 12 & 11 & 10 & 12.5 \\
\hline & \multicolumn{2}{|c|}{0.311} & \multicolumn{2}{|c|}{0.384} & \multicolumn{2}{|c|}{$0.024 *$} \\
\hline \multirow{2}{*}{$\begin{array}{l}\text { Sex } \\
\text { males } \\
\text { females } \\
\text { P value }\end{array}$} & $\begin{array}{l}1 \\
2\end{array}$ & $\begin{array}{c}11 \\
5\end{array}$ & $\begin{array}{l}6 \\
3 \\
\end{array}$ & $\begin{array}{l}6 \\
4 \\
\end{array}$ & $\begin{array}{l}4 \\
3 \\
\end{array}$ & $\begin{array}{l}8 \\
4 \\
\end{array}$ \\
\hline & \multicolumn{2}{|c|}{0.243} & \multicolumn{2}{|c|}{0.763} & \multicolumn{2}{|c|}{0.678} \\
\hline \multirow{2}{*}{$\begin{array}{l}\text { Median Hb } \\
\text { P value }\end{array}$} & 9 & 6.1 & 6.8 & 6.6 & 6 & 7 \\
\hline & \multicolumn{2}{|c|}{0.308} & \multicolumn{2}{|c|}{0.410} & \multicolumn{2}{|c|}{0.336} \\
\hline \multirow{2}{*}{$\begin{array}{l}\text { Median Blasts } \\
\text { P value }\end{array}$} & 78 & 59.5 & 66 & 58 & 56 & 63.5 \\
\hline & \multicolumn{2}{|c|}{0.0503} & \multicolumn{2}{|c|}{0.348} & \multicolumn{2}{|c|}{0.195} \\
\hline \multirow{2}{*}{$\begin{array}{l}\text { Median TLC } \\
\text { P value }\end{array}$} & 96 & 57.5 & 88 & 57 & 74 & 71 \\
\hline & \multicolumn{2}{|c|}{0.144} & \multicolumn{2}{|c|}{0.219} & \multicolumn{2}{|c|}{0.489} \\
\hline \multirow{2}{*}{$\begin{array}{l}\text { Median Platelets } \\
\mathrm{P} \text { value }\end{array}$} & 82 & 95 & 82 & 104 & 88 & 95 \\
\hline & \multicolumn{2}{|c|}{0.218} & \multicolumn{2}{|c|}{0.087} & \multicolumn{2}{|c|}{0.182} \\
\hline
\end{tabular}

$\mathrm{Hb}=$ Hemoglobin, TLC = Total Leucocytic Count, FLT-3 ITD = FMS-like tyrosine kinase-3 Internal Tandem Duplication, cMPL = Myeloproliferative leukemia virus oncogene, EphA4 = Ephrin A 4 receptor. 
Table 6: Correlation between the studied markers and CD34 and CD33 expression in adult AML.

\begin{tabular}{|c|c|c|c|c|c|c|}
\hline \multirow{3}{*}{ Marker } & \multicolumn{3}{|c|}{ CD34 } & \multicolumn{3}{|c|}{ CD33 } \\
\hline & \multicolumn{2}{|c|}{ Percentage $\%$} & \multirow[t]{2}{*}{ P value } & \multicolumn{2}{|c|}{ Percentage $\%$} & $P$ value \\
\hline & $\begin{array}{l}\text { +ve } \\
(25)\end{array}$ & $\begin{array}{l}\text {-ve } \\
(14)\end{array}$ & & $\begin{array}{l}\text { +ve } \\
(30)\end{array}$ & $\begin{array}{l}\text {-ve } \\
(9)\end{array}$ & \\
\hline $\begin{array}{c}\text { Flt-3 ITD } \\
+ \text { ve } \\
\text {-ve }\end{array}$ & $\begin{array}{l}14 \\
11\end{array}$ & $\begin{array}{c}0 \\
14\end{array}$ & $0.00047 * *$ & $\begin{array}{l}11 \\
19\end{array}$ & $\begin{array}{l}3 \\
6\end{array}$ & 0.854 \\
\hline $\begin{array}{c}\text { cMPL } \\
+ \text { ve } \\
\text {-ve }\end{array}$ & $\begin{array}{c}25 \\
0\end{array}$ & $\begin{array}{l}5 \\
9\end{array}$ & $<0.05^{*}$ & $\begin{array}{c}22 \\
8\end{array}$ & $\begin{array}{l}8 \\
1\end{array}$ & \\
\hline $\begin{array}{c}\text { EphA4 } \\
\text { +ve } \\
\text {-ve }\end{array}$ & $\begin{array}{l}14 \\
11\end{array}$ & $\begin{array}{l}8 \\
6\end{array}$ & 0.944 & $\begin{array}{l}18 \\
12\end{array}$ & $\begin{array}{l}4 \\
5\end{array}$ & 0.49 \\
\hline
\end{tabular}

FLT-3 ITD = FMS-like tyrosine kinase-3 Internal Tandem Duplication, $\mathrm{cMPL}=$ Myeloproliferative leukemia virus oncogene, EphA4 = Ephrin A 4 receptor. $*=$ statistical significance at $\mathrm{P}<0.05$.

Table 7: Correlation between the studied markers and CD34 and CD33 expression in pediatric AML patients.

\begin{tabular}{|c|c|c|c|c|c|c|}
\hline \multirow{3}{*}{ Marker } & \multicolumn{3}{|c|}{ CD34 } & \multicolumn{3}{|c|}{ CD33 } \\
\hline & \multicolumn{2}{|c|}{ Percentage \% } & \multirow[t]{2}{*}{$P$ value } & \multicolumn{2}{|c|}{ Percentage \% } & $P$ value \\
\hline & $\begin{array}{c}+ \text { ve } \\
(8)\end{array}$ & $\begin{array}{c}\text {-ve } \\
(11)\end{array}$ & & $\begin{array}{c}\text { +ve } \\
(17)\end{array}$ & $\begin{array}{l}\text {-ve } \\
(2)\end{array}$ & \\
\hline $\begin{array}{c}\text { Flt-3 ITD } \\
+\mathrm{ve} \\
-\mathrm{ve}\end{array}$ & $\begin{array}{l}3 \\
5\end{array}$ & $\begin{array}{c}0 \\
11\end{array}$ & $0.026^{*}$ & $\begin{array}{c}3 \\
14\end{array}$ & $\begin{array}{l}0 \\
2\end{array}$ & 0.854 \\
\hline $\begin{array}{c}\text { cMPL } \\
\text { +ve } \\
\text {-ve }\end{array}$ & $\begin{array}{l}7 \\
1\end{array}$ & $\begin{array}{l}2 \\
9\end{array}$ & $<0.0028 * *$ & $\begin{array}{c}7 \\
10\end{array}$ & $\begin{array}{l}2 \\
0\end{array}$ & 0.115 \\
\hline $\begin{array}{c}\text { EphA4 } \\
\text { +ve } \\
\text {-ve }\end{array}$ & $\begin{array}{l}4 \\
4\end{array}$ & $\begin{array}{l}3 \\
8\end{array}$ & 0.310 & $\begin{array}{c}6 \\
11\end{array}$ & $\begin{array}{l}1 \\
1\end{array}$ & 0.68 \\
\hline
\end{tabular}

FLT-3 ITD = FMS-like tyrosine kinase-3 Internal Tandem Duplication, $\mathrm{cMPL}=$ Myeloproliferative leukemia virus oncogene, EphA4 = Ephrin A 4 receptor. $*=$ statistical significance at $\mathrm{P}<0.05$. 


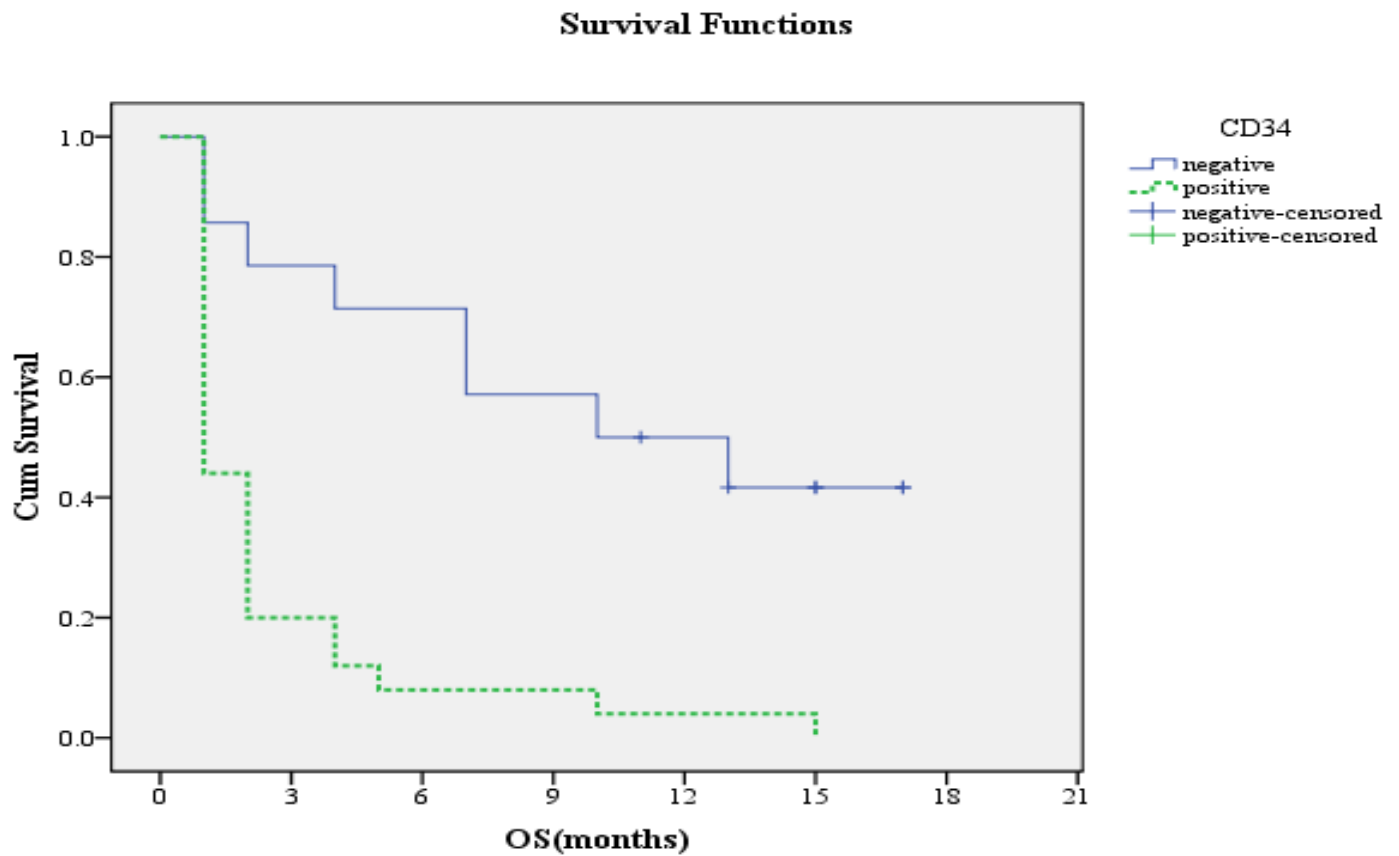

Fig. (1): The overall survival between patients negative and positive for CD34 expression ( $<0.001)$.

\section{Survival Functions}

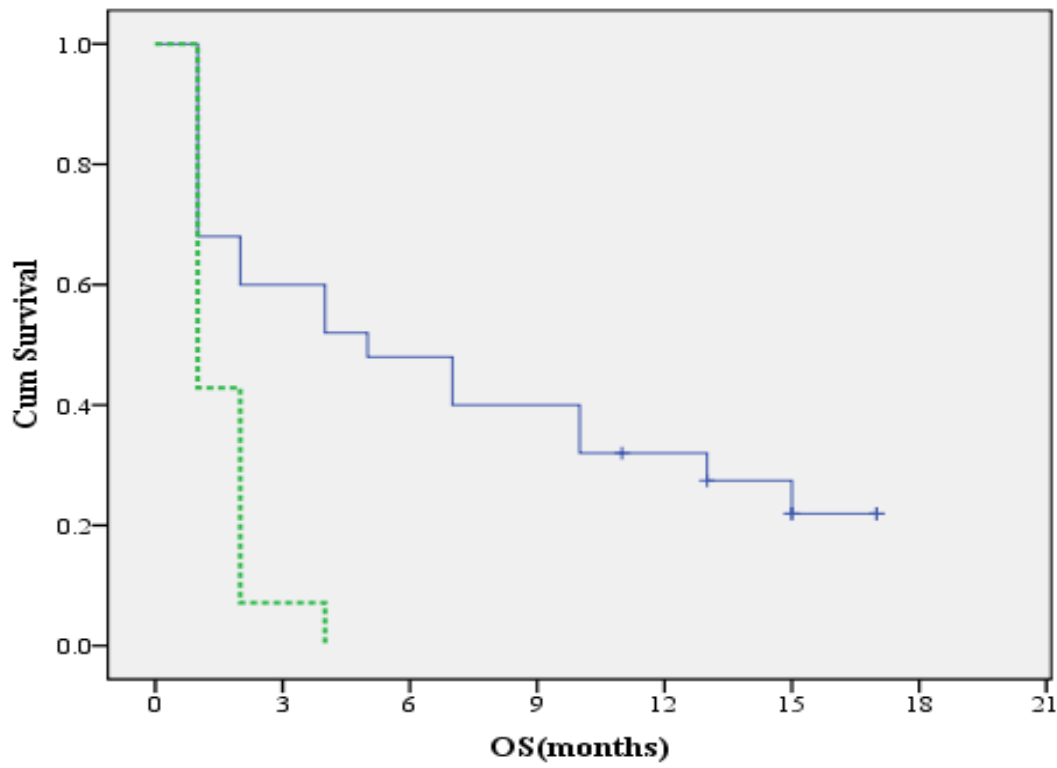

OS(months)

Fig. (2): The overall survival between patients negative and positive for FLT-3 ITD mutation $(\mathrm{P}<0.001)$.

In the present work we studied the status of 3 genes Fms-like tyrosine kinase 3 (FLT3 ITD) mutation, myeloproliferative leukemia protein (cMPL) and Ephrin type $\mathrm{A}$ receptor 4 (EPhA4) in adult and pediatric patients. We also studied CD34 and CD 33 status in the studied cases then we correlated the 3 markers to both CD33 and CD34 expression and the clinicopathological parameters.
Grunwald et al. ${ }^{[14]}$ detected FLT3 ITD mutation in 7 of the $28(25 \%)$ patients with acute myeloid leukemia. While Tian et al. ${ }^{[15]}$ studied FLT3 status in cytogenetically normal AML cases; he found that $31.6 \%$ of cases had FLT3 internal tandem duplications (ITDs) while $6.2 \%$ of the cases had FLT3 mutations. Also Gritsaev et al. ${ }^{[16]}$ examined the bone marrow specimens of 101 for FLT3-ITD mutation where twenty one patients had FLT3 mutation. 
Wetzler et al. ${ }^{[17]}$ found that 27 out of $45(60 \%)$ bone marrow samples of newly diagnosed AML cases expressed c-MPL by reverse-transcription polymerase chain reaction.

Although EphA4 expression was studied in many types of solid tumors ${ }^{[\mathbf{8}-12]}$, little information is known about its expression in AML.
Our study showed that AML cases expressing CD33 are higher than those expressing CD34 in both adults and pediatric patients. These results are in agreement with other studies that showed 85-90\% of AML cases express the CD33 antigen ${ }^{[18]}$. Also Yang et al. ${ }^{[19]}$ showed that 93\% of newly diagnosed AML cases express CD33, while the overall positive rate of CD34 was $57.8 \%$.

\section{Survival Functions}
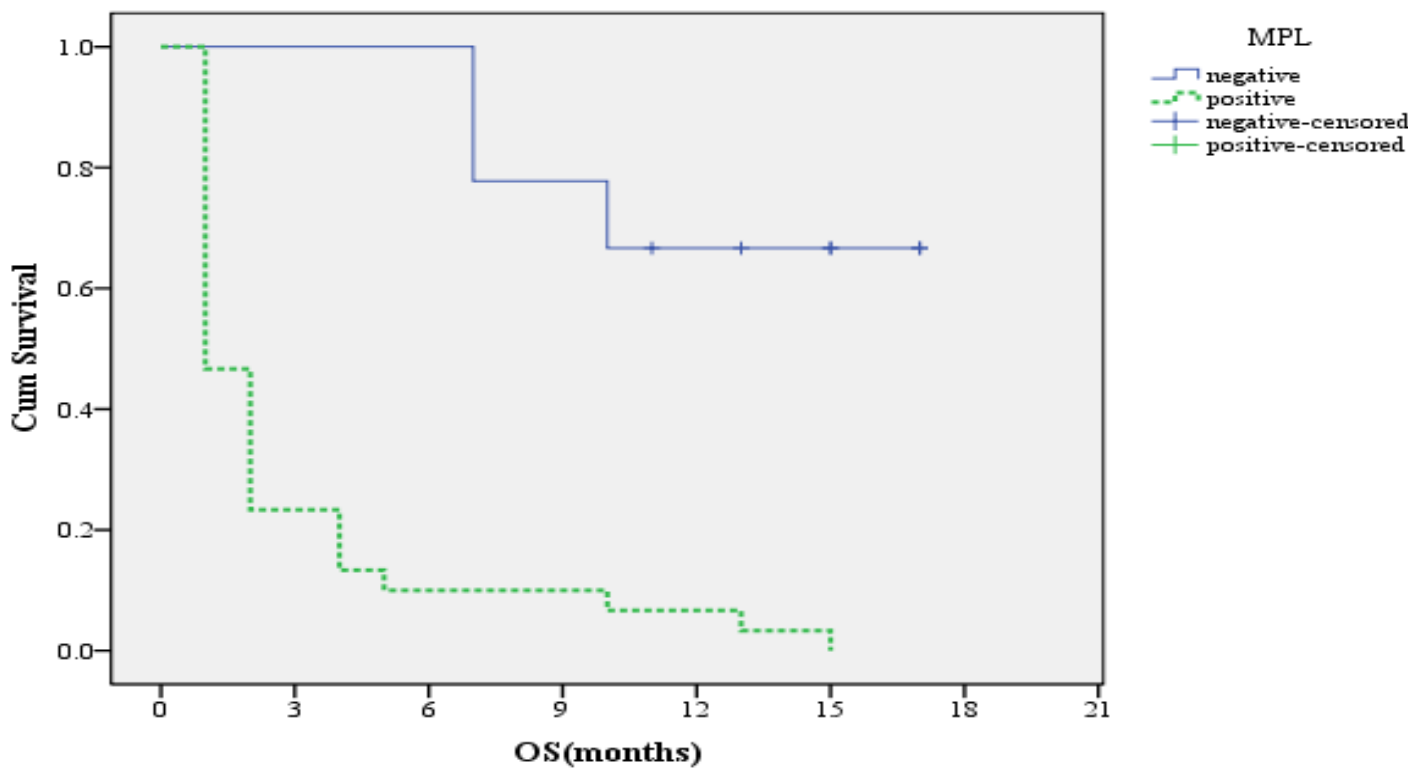

positive-censored

Fig. (3): The overall survival between patients negative and positive for cMPL mutation $(\mathrm{P}<0.001)$.

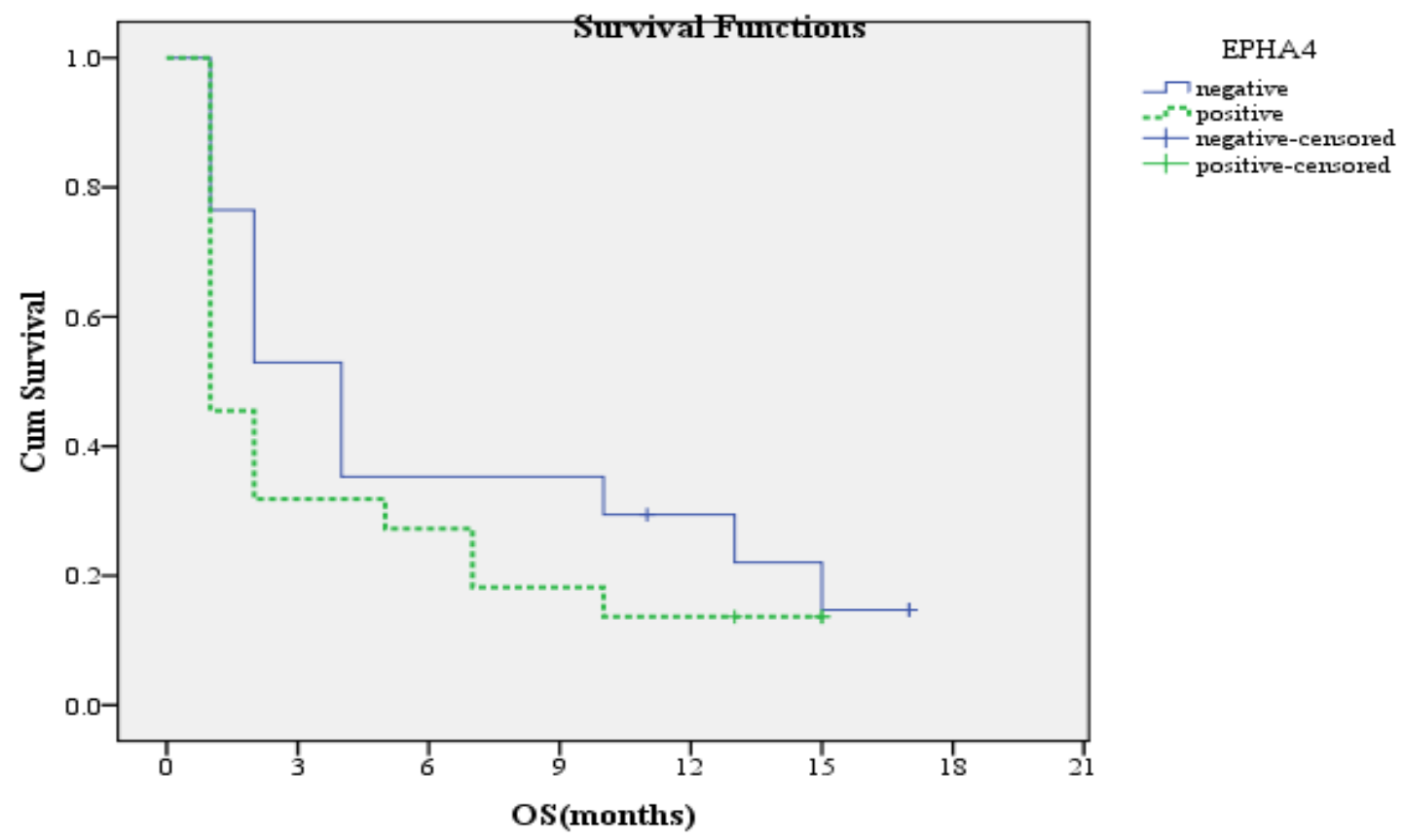

Fig. (4): The overall survival between patients negative and positive for EphA4 (P 0.312). 
We also found that FLT3 ITD mutation and the expression of both cMPL and EPHA 4 was higher in adults than pediatric AML patients. Iwai et al. ${ }^{[20]}$ found a significantly lower incidence of the FLT3 internal tandem duplication in childhood AML patients than in adult patients. Many other studies found that the frequency of FLT3/ITD positivity is lower in children than that reported in the adult series ${ }^{\text {[21-24] }}$.

In our study we found that CD34 expression is significantly correlated to FLT3 ITD mutation. Bakul $\boldsymbol{e t}$ al. ${ }^{[25]}$ studied NPM1, FLT3 ITD and a group of cell surface marker proteins including CD34 on 83 patients with cytogenetically normal AML, they indicated that FLT3-ITD cases were more likely to express CD34.

Regarding cMPL, our study indicated that there is a highly significant correlation between CD34 expression and cMPL expression. Ayala et al. ${ }^{[26]}$ found that cMPL expression is significantly correlated to CD34 expression in a group of 41 AML patients. Yu et al. ${ }^{\text {[27] }}$ correlated the expression of c-MPL to CD34 and CD38 expression in AML, he found that the expression of cMPL is higher in AML patients, and positively correlates with the expression level of CD34.

The positive correlation between CD34 expression, FLT3 ITD mutation and cMPL expression may indicate a mechanism that may correlate CD34 to both markers. Further studies are needed to investigate the nature of this correlation and the mechanism(s) that may correlate the 3 markers.

For the survival analysis, our study showed that FLT-3 negative patients had longer OS than FLT-3/ITD mutant patients. Karabacak et al. ${ }^{[28]}$ studied FLT3/ITD mutation in 40 AML patients he found that patients with negative FLT3 mutation had longer overall survival than FLT3/TID mutant patients but not disease free survival. Similarly Wang et $\boldsymbol{a l}$. ${ }^{[29]}$ studied FLT3/ITD and NPM1 mutations in 76 acute myeloid leukemia patients and showed that FLT3/ITD-positive/NPM1 mutationnegative group had worse overall survival (OS) and relapse-free survival (RFS) among the 76 AML patients. Also Colovic et al. ${ }^{[30]}$ found that the presence of FLT3/ITD mutation was the most significant prognostic factor for overall survival in a group of 113 Serbian adult AML patients.

For cMPL, we found that patients negative for cMPL had significantly higher overall survival than those expressing cMPL. On the contrary, Alaya et al. ${ }^{[26]} \mathrm{did}$ not find any difference in overall survival and event free survival between patients with and without c-MPL expression in a group of 36 acute myeloid leukemia patients. Later on, the same author (Alaya et $\boldsymbol{a l}$.) confirmed his previously published data and found that there is no significant difference between AML patients with or without cMPL expression ${ }^{[31]}$.

For EPhA 4, although our study showed a higher expression of EphA4 than that reported in other studies (Wrobel et al. ${ }^{[32]}$ ), we did not find significance between its expression and the overall survival in our study group.
Our result is contradicting with the results of Oki $\boldsymbol{e t}$ al. [33] where he found that EphA4 positive cases are significantly associated with low overall survival in 129 gastric cancer patients. The same results were found in breast cancer where EphA4 was negatively correlated to overall survival ${ }^{[34]}$. This may indicate that EPHA 4 expression may affect the survival of solid tumors but not AML.

\section{Conclusion:}

From the present study we may conclude that CD34 expression is significantly associated with both FLT-3 ITD mutation and cMPL expression which could be used as a marker for low survival. Normal FLT3 and the negative expression of both CD34 and cMPL, may predict a longer overall survival. Further studies are needed to investigate the mechanism (s) that may correlate CD34 to both markers.

\section{Declaration of conflict of Interest:}

The authors declare that they have no conflict of interest. No financial support or incentive from any source has been provided for this article.

\section{Funding:}

This research received no specific grant from any funding agency in the public, commercial or not forprofit sectors.

\section{References}

1) Stone, R. M., O'Donnell, M. R. and Sekeres, M. A. (2004). Acute myeloid leukemia. Hematology Am Soc Hematol Educ Program. 98-117.

2) Kumar, C. C. (2011). Genetic Abnormalities and Challenges in the Treatment of Acute Myeloid Leukemia. Genes Cancer, 2(2): 95-107.

3) Markovic, A., MacKenzie, K. L. and Lock, R. B. (2005). FLT-3: a new focus in the understanding of acute leukemia. Int J Biochem Cell Biol., 37(6): 1168-1172.

4) Pulikkan, J. A., Madera, D., Xue, L., Bradley, P., Landrette, S. F., Kuo, Y. H., Abbas, S., Zhu, L. J., Valk, P. and Castilla, L. H. (2012). Thrombopoietin/MPL participates in initiating and maintaining RUNX1-ETO acute myeloid leukemia via PI3K/AKT signaling. Blood. 120(4):868-879.

5) Schröder, J. K., Kolkenbrock, S., Tins, J., Kasimir-Bauer, S., Seeber, S. and Schütte, J. (2000). Analysis of thrombopoietin receptor (cMPL) mRNA expression in de novo acute myeloid leukemia. Leuk Res. 24(5):401-409.

6) Pasquale, E. B. (2005). Eph receptor signalling casts a wide net on cell behavior. Nat Rev Mol Cell Biol. 6: 462-475.

7) Genander, M. and Frisén, J. (2010). Ephrins and Eph receptors in stem cells and cancer. Curr opin Cell Biol. 22(5): 611-616.

8) Giaginis, C., Tsoukalas, N., Bournakis E, Alexandrou, P., Kavantzas, N., Patsouris, E. and Theocharis, S. (2014). (Eph) receptor A, A4, A5 
and A7 expression in human non-small cell lung carcinoma: associations with clinicopathological parameters, tumor proliferative capacity and patients survival. BMC Clin Pathol.;14(1):8.

9) Liu, C., Huang, H., Wang, C., Kong, Y. and Zhang, H. (2014). Involvement of ephrin receptor A4 in pancreatic cancer cell motility and invasion. Oncol Lett.7(6):2165-2169.

10) Miyazaki, K., Inokuchi1, M., Takagi, Y., Kato, K., Kojima, K. and Sugihara, K.. (2013). EphA4 is a prognostic factor in gastric cancer. BMC Clinical Pathology. 13:19.

11) Vaught, D., Brantley-Sieders D. M. and Chen J. (2008). Eph receptors in breast cancer: roles in tumor promotion and tumor suppression. Breast Cancer Research., 10:217.

12) Pasquale, E. B. (2010). Eph receptors and ephrins in cancer: bidirectional signalling and beyond. Nature Reviews Cancer. 10, 165-180.

13) Hasserjian, R. P. (2013). Acute myeloid leukemia: advances in diagnosis and classification. Int $\mathbf{J} \mathrm{Lab}$ Hematol. 35(3):358-366.

14) Grunwald, M. R., Tseng, L. H., Lin, M. T., Pratz, K. W., Eshleman, J. R., Levis, M. J. and Gocke, C. D. (2014). Biol Blood Marrow Transplant. Improved FLT3/ITD PCR assay predicts outcome following allogeneic transplant for AM. pii: S10838791(14)00531-X.

15) Tian X1, Xu Y, Yin J, et al. (2014). TET2 gene mutation is unfavorable prognostic factor in cytogeneticallynormal acute myeloid leukemia patients with NPM1+ and FLT3-ITD -mutations. Int J Hematol. 100(1):96-104.

16) Gritsaev, S. V., Martynkevich, I. S., Chubukina, Zh. V., et al. (2014). The specific features of the immunophenotype of blast cells in patients with de novo normal karyotype acute myeloid leukemia and FLT3-ITD mutation. Ter Arkh. 86(3):71-77.

17) Wetzler, M., Baer, M. R., Bernstein, S. H., et al, (1997). Expression of c-mpl mRNA, the receptor for thrombopoietin, in acute myeloid leukemia blasts identifies a group of patients with poor response to intensive chemotherapy. J Clin Oncol.;15(6):2262-8.

18) Sievers, E. L., Larson, R. A., Stadtmauer, E. A., et al, (2012). Efficacy and safety of gemtuzumab ozogamicin in patients with CD33positive acute myeloid leukemia in first relapse. J Clin Oncol. 19(13):3244-3254.

19) Yang, L. L., Liu, X., Li, Q., Zhu, X. Y., Wang, X. B., Zhu, W. B. (2014). Immunophenotyping characteristics of AML and their correlation with the curative effects. Zhongguo Shi Yan Xue Ye Xue Za Zhi. 22(1):1-5.

20) Iwai, T., Yokota, S., Nakao, M., et al. (1999). Internal tandem duplication of the FLT3 gene and clinical evaluation in childhood acute myeloid leukemia. The Children's Cancer and Leukemia Study Group, Japan. Leukemia. 13(1):38-43.
21) Stirewalt, D. L., Kopecky, K. J., Meshinchi, S., et al. (2001). FLT3, RAS, and TP53 mutations in elderly patients with acute myeloid leukemia. Blood. 97:3589-3595.

22) Kottaridis, P. D., Gale, R. E., Frew, M. E., et al. (2001). The presence of a FLT3 internal tandem duplication in patients with acute myeloid leukemia (AML) adds important prognostic information to cytogenetic risk group and response to the first cycle of chemotherapy: analysis of 854 patients from the United Kingdom Medical Research Council AML 10 and 12 trials.; Blood. 98:1752-1759.

23) Schnittger, S., Schoch, C., Dugas, M., et al. (2002). Analysis of FLT3 length mutations in 1003 patients with acute myeloid leukemia: correlation to cytogenetics, FAB subtype, and prognosis in the AMLCG study and usefulness as a marker for the detection of minimal residual disease. Blood, 100:5966.

24) Thiede, C., Steudel, C., Mohr, B., et al. (2002). Analysis of FLT3-activating mutations in 979 patients with acute myelogenous leukemia: association with FAB subtypes and identification of subgroups with poor prognosis. Blood, 99:4326-4335.

25) Dalal, B. I., Mansoor, S., Manna, M., Pi, S., Sauro, G. D. and Hogge, D. E. (2012). Detection of CD34, TdT, CD56, CD2, CD4, and CD14 by flow cytometry is associated with NPM1 and FLT3 mutation status in cytogenetically normal acute myeloid leukemia. Clin Lymphoma Myeloma Leuk. 12(4):274-279.

26) Ayala, R. M., Martínez-López, J., Albízua, E., Diez, A. and Gilsanz, F. (2009). Clinical significance of Gata-1, Gata-2, EKLF, and c-MPL expression in acute myeloid leukemia. Am J Hematol. 84(2):79-86.

27) Yu, P., Qiu, S. W., Rao, Q., et al. (2012). Expression of c-MPL in leukemic stem cells from acute myeloid leukemia patients. Zhongguo Shi Yan Xue Ye Xue Za Zhi. 20(5):1052-1055.

28) Karabacak, B. H., Erbey, F., Bayram, I., et al. (2010). Fms-like tyrosine kinase 3 mutations in childhood acute leukemias and their association with prognosis. Asian Pac J Cancer Prev. 11(4):923-927.

29) Wang, L., Xu, W. L., Meng, H. T., et al.. (2010). FLT3 and NPM1 mutations in Chinese patients with acute myeloid leukemia and normal cytogenetics. J Zhejiang Univ Sci B. 11(10):762-770.

30) Colovic, N., Tosic, N., Aveic, S., et al. (2007). Importance of early detection and follow-up of FLT3 mutations in patients with acute myeloid leukemia. Ann Hematol., 86(10):741-747.

31) Ayala, R. M., Martínez-López, J. and Gilsanz, F. (2012). Acute myeloid leukemia and transcription factors: role of erythroid Krüppel-like factor (EKLF). Cancer Cell Int.; 12(1):12-25. 
32) Wrobel, T., Pogrzeba, J., Stefanko, E., Wojtowicz, M., Jazwiec, B., Dzietczenia, J., Mazur, G. and Kuliczkowski, K. (2014). Expression of Eph A4, Eph B2 and Eph B4 receptors in AML. Pathol Oncol Res. 20(4):901-7.
33) Oki, M., Yamamoto, H., Taniguchi, H., Adachi, A., Imai, K. and Shinomura, Y. (2008). Overexpression of the receptor tyrosine kinase EphA4 in human gastric cancers. World J Gastroenterol., 14(37): 5650-5656.

34) Brantley-Sieders, D. M., Jiang, A., Sarma, K., et al. (2011). Eph/Ephrin Profiling in Human Breast Cancer Reveals Significant Associations between Expression Level and Clinical Outcome. PLoS One, 6(9):e24426. 